IRA-International Journal of Education \&

Multidisciplinary Studies

ISSN 2455-2526; Vol.15, Issue 05 (Oct.-Dec. 2019)

Pg. no. 201-204.

Institute of Research Advances

http://research-advances.org/index.php/IJEMS

QUARTERLY

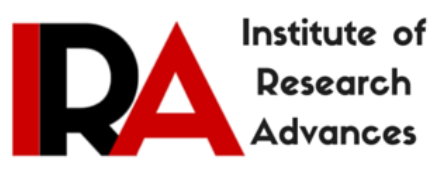

\title{
Business English Teaching Mode Under the Background of Big Data
}

Li Yan

School of Foreign Language, Yangtze University, Jingzhou, Hubei, P. R. China

Type of Work: Peer-Reviewed

DOl: http://dx.doi.org/10.21013/jems.v15.n5.p6

\section{How to cite this paper:}

Yan, L. (2019). Business English Teaching Mode Under the Background of Big Data. IRA International Journal of Education and Multidisciplinary Studies (ISSN 2455-2526), 15(5), 201-204.doi: http://dx.doi.org/10.21013/jems.v15.n5.p6

(C) Institute of Research Advances.

This work is licensed under a Creative Commons Attribution-Non Commercial 4.0 International License subject to a proper citation to the publication source of the work.

Disclaimer: The scholarly papers as reviewed and published by the Institute of Research Advances (IRA) are the views and opinions of their respective authors and are not the views or opinions of the IRA. The IRA disclaims of any harm or loss caused due to the published content to any party.

Institute of Research Advances is an institutional publisher member of Publishers International Linking Association Inc. (PILA-CrossRef), USA. The institute is an institutional signatory to the Budapest Open Access Initiative, Hungary advocating the open-access of scientific and scholarly knowledge. The Institute is a registered content provider under Open Access Initiative Protocol for Metadata Harvesting (OAl-PMH).

The journal is indexed \& included in WorldCat Discovery Service (USA), CrossRef Metadata Search (USA), WorldCat (USA), OCLC (USA), Open J-Gate (India), EZB (Germany) Scilit (Switzerland), Airiti (China), Bielefeld Academic Search Engine (BASE) of Bielefeld University, Germany, PKP Index of Simon Fraser University, Canada. 


\section{ABSTRACT}

Based on big data, business English teaching mode is a reform of traditional teaching mode. It comprehensively records the teaching process through real-time data sharing. This paper discusses the application of "big data" in business English teaching design, teaching content, teaching methods and teaching evaluation. It is proposed that business English teaching mode under the background of big data can fully mobilize autonomy and creativity, which is conducive to deepening classroom teaching reform, carrying out all-round independent learning, strengthening daily teaching management, optimizing talent training mode and promoting educational informatization reform.

Keywords: big data, teaching mode, business English

\section{Introduction}

At present, people's development and utilization of the large-scale, intensive and intelligent data announce the arrival of the era of big data. According to the ten-year development plan of educational informatization (2011-2020) issued by the Ministry of Education, it is necessary to drive the modernization of education with educational informatization as a strategic choice, integrate the latest information technology into the modernization of education and teaching, and realize all-round innovation in the macro concept and micro practice of education. Digital teaching mode is a revolution from the traditional teaching mode, and its most prominent feature is data sharing. Data are collected through multiple channels such as flipped classroom, micro-class, MOOCs and autonomous learning to comprehensively record the teaching process and provide strong data support for business English teaching.

\section{Current Research Situation of Business English Teaching at Home and Abroad.}

Business English teaching can originate from the middle of the 16th century, but as subject research, it began in the 1990s. Dudley Evans \&St. John thinks that business English falls under the category of ESP (English for Specific Purposes) and can be divided into English for General Business Purposes (EGBP) and English for Specific Business Purposes (ESBP). After entering the new century, there are also some opinions that business English has become a part of English as a Lingua Franca and gradually developed into the common language of business English. Daniushina(2010) put forward the idea of establishing business linguistics, and further demonstrated the subject research range and major research points.

In China, business English teaching began in the early 1950s which was called foreign trade English. Then Lin Tianhu proposed the core concept and theoretical system of business English teaching in 2001. In 2004, Xiao Yunnan believes that business English should be included in the category of "interdisciplinary applied linguistics". Wang Lifei and other experts, when discussing on the basis of the theoretical system, orientation, connotation and academic focus of business English linguistics, proposed for the first time that business English linguistics theory consists of 13 parts.

\section{Big Data and Business English Teaching.}

Big data generally refers to all data sets related to the research objects, and these data sets are recording and influencing human activities in a brand-new manner. English teaching mode based on big data takes business English teaching as the carrier, integrates "teaching" and "learning" organically through real-time data sharing. The online teaching platform with abundant data resources can fully mobilize the autonomy and creativity of teachers and students, which can not only optimize the teaching design on the macro level but also provide data support on the micro-level. Meanwhile, People's development and utilization of large-scale, intensive and intelligent data have touched every 
corner of the society, influencing the world's present politics, economy, military, technology, culture, education and transportation etc., and it also influences the human's behaviour styles and psychological states in an unprecedented way.

\section{The Reform of Business English Teaching Mode Based on Big Data}

Business English teaching based on data platform is on account of the extension and development of Internet and multimedia studies. For teaching design, it can make an overall curriculum system according to different professional data information. For teaching content, it can select the real business English corpus from the cloud. For teaching method, it can share the newest teaching ideas and methods through real-time updated interactive data. On teaching evaluation, it can increasingly approach to the best mode by multipronged evaluative dimension. Thus the Business English teaching based on big data will be quite helpful to explore a mature and stable teaching method.

1. Teaching design.

Teachers should develop practical business English teaching aims according to course features and social demands and reasonably plan as a whole the relationship of business English courses and other courses, combining design module of business English with web-based teaching platform improve students' basic skills of using English in ordinary business activities which both pay attention to language skills and business skills.

2. Teaching contents.

Teachers should flexibly select interest-oriented and true business corpus. The selected materials should be novel and have a proper gradient, which focuses on that business culture shown in business activities and combine the business English content module with the latest business information. Students can study as a team and communicate with each other nicely. They also can seek help and upload studying materials online, poster their group works at a fixed period every week like a company or a club. The contents of their works include human resource, performance evaluation, product launch, advertising, business, consultation, business negotiations, logistics distribution, after-sales service, and complaint and rights protection and so on.

3. Teaching methods.

Relying on online teaching platform and by sharing the real-time data, the teachers can expand instructional interaction and also can monitor students' entire studying trend. They will pay more attention to students' individual differences and then improve students' self-learning ability and cognitive competence. For the traditional teaching method, all the teaching activities are around students, while in the new teaching method based on big data, both teachers and students are information senders and receivers and carriers. Also, the teachers can acquire first-hand teaching data through Flipped Classroom, Micro lecture, MOOCs etc, in this way, they can gain a whole picture of textbook and students, and make the classes more interesting and full of creative activities.

4. Teaching evaluation.

Teachers should combine evaluation module of business English with data analysis in the process of studying and concern about the formative evaluation of individual students. The real-time updating data platform is good for teachers and students to comprehensively know teaching information, to follow up with timely optional courses and syllabus. For the teachers, they will know the class attendance and the student's performances. In the teaching process, they can analyze errors. After all these teaching activities, the teachers and draw a clear growth track of every student according to data comparison and dimensional analysis. 


\section{Conclusion}

Compared with traditional teaching model, business English teaching mode based on big data not only has advantages in macro level, such as teaching design, teaching content teaching method and teaching evaluation but also can provide the first-hand data support in micro level, such as error analysis, data comparison, statistical scores and satisfactory survey etc.

Firstly, it is conducive to deepening the reform of classroom teaching. Teachers can obtain the first-hand teaching form of data through Flipped Classroom, MOOCs, Micro-class and other forms, which is not only beneficial to students' preview before class and after-class review. The teachers will be familiar with the key difficulties in each teaching process, which is conducive to teachers' overall understanding of the students' performances., In this way, they can understand the students' learning aptitude, and better to enhance the interest and intelligence of classroom teaching.

Secondly, it is beneficial to strengthen daily teaching management. The real-time updated data platform is conducive to students' comprehensive understanding of educational affairs information, real-time understanding of elective courses, course progress, attendance, performance and exam preparation, etc. Meanwhile, it is also helpful for teachers and administrative staff to ensure the orderly implementation the daily teaching activities.

Thirdly, it is beneficial to optimize the mode of talent training. Based on the value attribute of the data platform, it is beneficial for teachers and teaching administrators to select outstanding students and to classify the junior students. In view of the interdisciplinary nature of business English (Chen Zhunmin etc.2006:7), the construction of data platform will accelerate the integration of high-quality teaching resources and the implementation of application-oriented talent education in colleges and universities, so as to optimize the talent training mode and improve the competitiveness of students.

In a word, English teaching mode based on big data takes business English teaching as the carrier, integrates "teaching" and "learning" organically through real-time data sharing. The online teaching platform with abundant data resources can fully mobilize the autonomy and creativity of teachers and students, which can not only optimize the teaching design on the macro level but also provide data support on the micro-level.

\section{References:}

[1] Ellis, M \&Johnson, C Teaching Business English[M]. Shanghai: Shanghai Foreign Language Education Press, 2002.

[2] Daniushina, Y.V. Business linguistics and business. discourse[J].Kalaedoscope,2010(3)

[3] Chen Zhunmin. Strengthen the system of economic and trade English courses [A]. Lin Tianhu International business English studies in China[C]. Xiamen: Xiamen University Press, 1999:47-52.

[4] Business English theory research group of university of international business and economics on the subject orientation, research object and development direction of business English [J]. China' foreign language, 2006 (9).

[5] He Kekang. New progress in theoretical research on educational informatization in China [J]. China' audio-visual education, 2001 (1).

[6] Ruan Jizhi. Objectives and teaching principles of college business English [J]. Language world, 2005(3).

[7] Lei Chunling. Content teaching method (CBI) and compound foreign language teaching--take business English teaching model as an example [J]. Audio-visual teaching of foreign languages, 2006 (6). 